PSICOLOGIA, SAÚDE \& DOENÇAS, 2020, 21(3), 676-686

ISSN - 2182-8407

Sociedade Portuguesa de Psicologia da Saúde - SPPS - www.sp-ps.pt

DOI: http://dx.doi.org/10.15309/20psd210311

\title{
ATTENTION-DEFICIT/ HYPERACTIVITY DISORDER AND THE COVID-19 PANDEMIC
}

\author{
Rita Amorim ${ }^{1}$, Pedro Miragaia ${ }^{1}$, Sara Catarino ${ }^{1}$, Victor Viana $^{2}$, \& Micaela Guardiano ${ }^{3}$ \\ ${ }^{1}$ Pediatrics, Centro Hospitalar e Universitário São João, Porto, Portugal, rita.g.amorim@hotmail.com, \\ pedro.a.miragaia@gmail.com, sara.ccat@gmail.com \\ ${ }^{2}$ Psychology Department, Centro Hospitalar e Universitário São João, Porto, Portugal, victorviana@fcna.up.pt \\ ${ }^{3}$ Neurodevelopment Unit, Pediatrics, Centro Hospitalar e Universitário São João, Porto, Portugal, \\ mguardiano@hotmail.com
}

\begin{abstract}
Attention-Deficit/Hyperactivity Disorder (ADHD) symptoms is often associated with stress and anxiety. The COVID-19 pandemic forced families to adjust their lives, and the consequences on mental health are still unknown. We aim to explore how children with ADHD and their parents experienced the isolation during the COVID19 pandemic. This is the first study focusing children with ADHD and their parents, in Portugal, during the COVID-19 outbreak. We conducted an observational, cross-sectional and analytical study. An anonymous questionnaire was designed where the impact of the quarantine in different aspects of children's and their parent's daily life were included. Among the 152 questionnaires obtained, 90 were related to children with ADHD and 62 to children in the control group. Children with ADHD predominantly had changes in behavior while the healthy ones mostly had no changes $(p=0.035)$. Parents of ADHD children reported higher mean levels of stress than healthy ones and the same occurred in caregivers $(p<0.001)$. Caregivers experienced higher levels of anxiety than their children. Parents of ADHD children stated no impact in personal development $(p=0.05)$ and in family relations ( $p=0.021$ ) against those in control group reporting mostly positive impact of the quarantine in these aspects. Our results alert not only to the importance of focusing special vulnerable groups, but also the post-pandemic surveillance of mental disorders among families.
\end{abstract}

Keywords: Adaptive behaviour, ADHD, caregivers, COVID-19, mental health, stress.

\section{PERTURBAÇÃO DA HIPERATIVIDADE E DÉFICE DE ATENÇÃO E A PANDEMIA COVID-19}

RESUMO: Sintomas da Perturbação da Hiperatividade e Défice de Atenção (PHDA) são frequentemente associados a stress/ansiedade. A pandemia COVID-19 conduziu a uma necessidade de adaptação, cujas consequências na saúde mental se desconhecem. Pretendemos explorar como as crianças com PHDA e os seus cuidadores experienciaram o isolamento social durante a pandemia COVID-19. Este é o primeiro estudo realizado

\footnotetext{
Alameda Prof. Hernâni Monteiro, 4200-319 Porto. Phone: +351 913371529. Email: rita.g.amorim@hotmail.com
} 
em crianças com PHDA e seus cuidadores, em Portugal, durante este surto. Trata-se de um estudo observacional, transversal e analítico. Foi aplicado um questionário anónimo que inclui o impacto da quarentena, em diferentes aspetos das suas vidas e dos seus cuidadores. Foram obtidos 152 questionários, 90 de crianças com PHDA e 62 de crianças saudáveis. Crianças com PHDA tiveram predominantemente alterações do comportamento, enquanto as crianças saudáveis mantiveram, na maioria, o seu comportamento habitual $(p=0,035)$. Os pais das crianças com PHDA referiram maiores níveis de stress nas crianças do que os pais das crianças saudáveis e o mesmo aconteceu com os próprios $(p<0,001)$. Os cuidadores reportaram níveis de ansiedade mais elevados neles próprios do que nas crianças. A quarentena não teve impacto no desenvolvimento pessoal $(p=0,05)$ ou nas relações familiares $(p=0,021)$ das crianças com PHDA, ao contrário do grupo controlo em que houve um impacto positivo nestes aspectos. Os nossos resultados alertam não só para a importância de focalização em grupos vulneráveis, mas também na vigilância da saúde mental das famílias no período pós-pandemia.

Palavras-Chave: Comportamento adaptativo, COVID-19, cuidadores, PHDA, saúde mental, stress.

\section{Recebido em 21 de julho de 2020/ Aceite em 21 de setembro de 2020}

Attention-deficit/hyperactivity disorder (ADHD) is a neurodevelopmental disorder characterised by hyperactivity, inattentiveness and impulsiveness that interferes with functioning or development (American Academy of Pediatrics, 2000; American Psychiatric Associacion, 2003). ADHD is the most frequent neurobehavioral disorder among children, and can lead to numerous negative consequences in everyday life, including high levels of stress (Oster et al., 2020). Unpredictable situations and changes from the normal routine were stated to be common precursors of stress in this population (Oster et al., 2020; Reimherr et al., 2017). ADHD symptoms such as irritability, behavioral problems like aggressiveness and oppositional behavior are also often described as strong predictor to parenting stress (Craig et al., 2020), having parents of children with ADHD higher rates of stress and mental health difficulties than parents of typically developing children (Cheung \& Theule, 2016; Martin et al., 2019; Schroeder, \& Kelley, 2009; Silva et al., 2015).

On March 11, 2020, the World Health Organization (WHO), has declared the novel coronavirus (COVID-19) outbreak a global pandemic (World Health Organization [WHO], 2020). In Portugal, schools closed on March 13, forcing children to stay at home. Some of them started to get homework from their teachers on a daily basis, while others took classes using videocall. Furthermore, in an attempt to maintain the access to education universal and overcome inequalities, Portuguese Government began broadcasting classes through television (República Portuguesa, 2020).

The COVID-19 pandemic brought a humanitarian challenge (Wagner, 2020), forcing families to adjust their lives, struggling with the fear of the disease (Shuja et al., 2020), social isolation, remote work and at the same time having to be "teachers" of their own children.

This study aims to explore how children with ADHD and their parents experience the isolation in their homes during school closedown in the COVID-19 pandemic. We hypothesised that parents of children with ADHD would report higher rates of stress and lower rates of adaptive capacity in regard to themselves and their children compared to parents of children without neurobehavioral disorders during this time.

To our knowledge, this is the first study focusing children with ADHD and their parents, in Portugal, during the COVID-19 outbreak. 


\section{ATTENTION-DEFICIT/ HYPERACTIVITY DISORDER \& COVID19}

\section{METHOD}

We conducted an observational, cross-sectional and analytical study. An anonymous questionnaire was designed where children's demographic and clinical characteristics, as well as the impact of the quarantine in different aspect of theirs' and their parent's daily life were included, with a total of 21 groups of questions (Table 1). The variables "anxiety levels" and "adaptation to quarantine" were asked to be scored from 0 (no anxiety/inadaptation to the quarantine) to 10 (maximum anxiety/total adaptation to the quarantine).

Parents of 150 children with ADHD diagnosis, as well as 100 parents of children without neurodevelopment disease (control group) were contacted by telephone or by e-mail (through online form) during April 2020. Questionnaires related to parents who didn't want to reply or didn't answer phone calls were excluded, as well as questionnaires related to children younger than 6 or older than 18 year old.

Variable descriptive analysis was performed. This included frequencies and percentages for categorical variables and mean and standard deviations for continuous variables. Comparison between ADHD group with control group was performed using Student's t-test and Chi-square. All reported values of $p$ were two-tailed, with a 0.05 significance level $(\alpha)$. Data analysis was carried out using SPSS ${ }^{\circledR}$ software, version 24. 
Table 1. Questionnaire variables

\section{DEMOGRAPHIC CHARACTERISTICS}

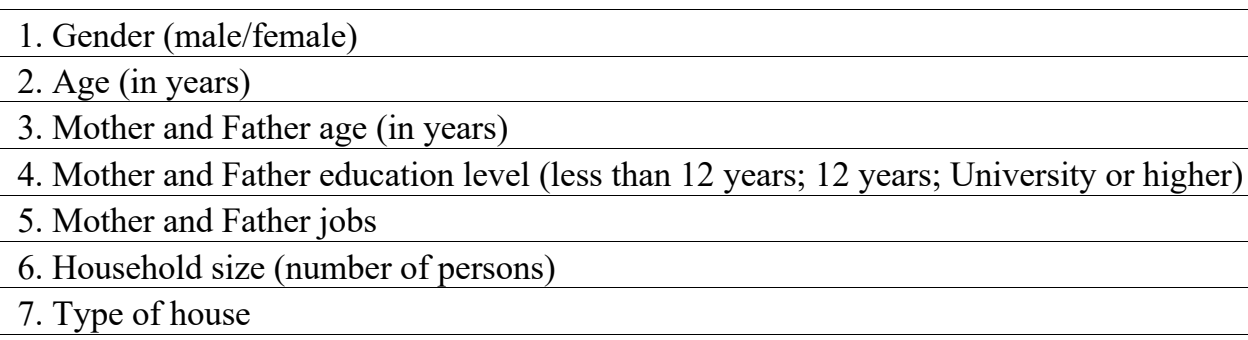

With/without outdoor space Apartment/Villa

PERSONAL HISTORY

8. Medical history

ADHD diagnosis

None/Other diseases

\section{QUARANTINE DETAILS}

9. First day of quarantine

10. How long is the child at home? (in days)

11. Did the child already went out? (Yes/No)

If yes, how many times?

12. Did school provide home classes? (Yes/No)

13. Extracurricular activities before quarantine (Yes/No)

If yes, did he/she maintain it?

14. Did child maintain routines at home? (Yes/No)

15. Were tasks at home given to the child? (Yes/No)

16. Did the child's behavior change? (Yes/No)

If yes, for better or for worse? And what was the biggest change?

17. Impact of the quarantine in:

18. Child anxiety score ( 0 to 10$)$

Relation with relatives (Positive/Negative/None)

19. Caregivers anxiety score (0 to 10$)$

20. Child adaptation to quarantine score ( 0 to 10$)$

21. Caregivers adaptation to quarantine score ( 0 to 10 )

22. Biggest challenge/difficulty to children and caregivers during quarantine

\section{RESULTS}

Among the 152 questionnaires obtained, 90 were related to children diagnosed with ADHD and 62 to children in the control group. Results respecting to demographic characteristics are shown in Table 2. 


\section{ATTENTION-DEFICIT/ HYPERACTIVITY DISORDER \& COVID19}

Table 2. Results concerning to demographic characteristics

\begin{tabular}{|c|c|c|c|c|}
\hline & All $(n=152)$ & ADHD $(n=90)$ & Control $(n=62)$ & p value \\
\hline Age (yrs) - mean $\pm S D$ & 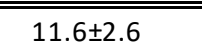 & $\overline{111.9 \pm 2.4}$ & 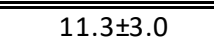 & 0.186 \\
\hline Gender - n (\%) & & & & 0.007 \\
\hline Male & $100(65.8)$ & $67(74.4)$ & $33(53.2)$ & \\
\hline Female & $52(34.2)$ & $23(25.6)$ & $29(46.8)$ & \\
\hline School grade (yrs) - mean \pm SD & $6.04 \pm 2.59$ & $6.19 \pm 2.39$ & $5.82 \pm 2.87$ & 0.395 \\
\hline Mother age (yrs) - mean $\pm S D$ & $42.74 \pm 5.47$ & $41.92 \pm 6.60$ & $44.00 \pm 3.74$ & 0.03 \\
\hline Mother education - $\mathrm{n}(\%)$ & & & & $p<0.001$ \\
\hline$<12 \mathrm{yrs}$ & $44(28.9)$ & $38(42.2)$ & $6(9.7)$ & \\
\hline $12 \mathrm{yrs}$ & $41(27.0)$ & $31(34.4)$ & $10(16.1)$ & \\
\hline University & $65(42.8)$ & $21(23.3)$ & $44(71.0)$ & \\
\hline Mother job - n (\%) & & & & $p<0.001$ \\
\hline Indeferenciate & $6(3.9)$ & $6(6.7)$ & 0 & \\
\hline Manual job & $53(34.9)$ & $45(50.0)$ & $8(12.9)$ & \\
\hline Specialized manual job & $24(15.8)$ & $17(18.9)$ & $7(11.3)$ & \\
\hline Scientific jobs & $40(26.3)$ & $10(11.1)$ & $30(48.4)$ & \\
\hline Technicals & $28(18.4)$ & $12(13.3)$ & $16(25.8)$ & \\
\hline Father age (yrs) - mean $\pm S D$ & $44.04 \pm 6.05$ & $43.12 \pm 6.89$ & $45.32 \pm 4.39$ & 0.022 \\
\hline Father education - $\mathbf{n}(\%)$ & & & & $p<0.001$ \\
\hline$<12 \mathrm{yrs}$ & $52(34.3)$ & $19(21.1)$ & $6(9.7)$ & \\
\hline $12 \mathrm{yrs}$ & $32(21.1)$ & $46(51.1)$ & $13(21.0)$ & \\
\hline University & $60(39.5)$ & $18(20.0)$ & $42(67.7)$ & \\
\hline Father job - $\mathrm{n}(\%)$ & & & & $p<0.001$ \\
\hline Indeferenciate & $8(5.3)$ & $7(7.8)$ & $1(1.6)$ & \\
\hline Manual job & $41(27.0)$ & $37(41.1)$ & $4(6.5)$ & \\
\hline Specialized manual job & $36(23.7)$ & $11(12.2)$ & $25(40.3)$ & \\
\hline Scientific jobs & $35(23.0)$ & $23(25.6)$ & $12(19.4)$ & \\
\hline Technicals & $24(15.8)$ & $5(5.6)$ & $19(30.6)$ & \\
\hline Household size - mean \pm SD & $3.66 \pm 0.89$ & $3.63 \pm 0.89$ & $3.69 \pm 0.88$ & 0.682 \\
\hline Type of habitation - $\mathbf{n}(\%)$ & & & & $0.426^{*}$ \\
\hline Apartment with outdoor space & $41(27.0)$ & $24(26.7)$ & $17(27.4)$ & \\
\hline Apartment witout outdoor space & $41(27.0)$ & $27(30.0)$ & $14(22.6)$ & \\
\hline Villa with outdoor space & $68(44.7)$ & $37(41.1)$ & $31(50.0)$ & \\
\hline Villa without outdoor space & $2(1.3)$ & $2(2.2)$ & 0 & \\
\hline
\end{tabular}

${ }^{*} p=0.837$ if both groups are compared considering houses with outdoor space vs houses without outdoor space

Mean age of all studied children was $11.6( \pm 2.6)$ years, with predominance of boys $(65.8 \%)$. Parents were predominantly university educated (42.8\% for mothers and $39.5 \%$ for fathers), and children were in average in their $6^{\text {th }}$ grade $(6.04 \pm 2.59$ years $)$. They mostly live in villas with outdoor space $(44.7 \%)$, with a mean household size of $3.66( \pm 0.89)$ persons, and we found no statistically significant differences between both groups in these two variables ( $p=0.426$ for house type and $p=0.682$ for household size).

Regarding most of the quarantine details results (Table 3), on average, all the investigated children were in quarantine day $33.2( \pm 5.8)$ at the time of questionnaire filling, without statistically significant difference between ADHD and control group ( $p=0.157)$, and most children (57.2\%) already went out at least one time during that period.

The great majority of children were provided with home school classes $(71.7 \%)$, and there was a statistical significant difference in the proportion of providence between ADHD and control groups (62.2\% in ADHD vs. $85.5 \%$ in control, $p=0.002$ ).

When asked if their children had changes in behavior, parents of children with ADHD predominantly agreed $(51.1 \%)$, being the most frequently described changes in behavior anxiety and 
agitation, while parents of the healthy ones mostly found no changes $(66.1 \%)$, and differences between these groups were statistically different $(p=0.035)$.

Concerning to the quarantine's impact in learning, both ADHD and control group's parents reported mostly negative impacts $(56.7 \%$ in $\mathrm{ADHD}$ and $51.6 \%$ in controls), and we found no statistically significant differences between the groups $(p=0.599)$. We also found no statistically significant differences in the reports of the quarantine's impact in emotion management $(p=0.387)$.

On the other hand, the impact of the quarantine in personal development $(p=0.05)$ and in family relations ( $p=0.021$ ) was statistically different between ADHD and control groups, with the majority of parents of ADHD children reporting no impact in personal development (43.3\%) and in family relations $(53.3 \%)$ against those in control group reporting mostly positive impact of the quarantine in personal development (41.9\%) and in family relations $(56.5 \%)$.

In what concerns to the reported anxiety levels imposed by the quarantine, ADHD children had higher mean levels $(5.34 \pm 2.68)$ than healthy ones $(3.65 \pm 2.61)$ and the same occurred in caregivers of ADHD children (7.27 \pm 2.35$)$ versus those of the healthy group (5.52 \pm 2.28$)$. All these differences were statistically significant $(p<0.001)$. We also highlight the fact that caregivers have higher mean scores of anxiety levels than their children.

Regarding to the ability of adaptation to the quarantine, we found no statistically significant differences in mean scores either in children (7.03 \pm 1.94 in ADHD group versus 7.29 \pm 2.55 in control group, $p=0.504)$ or in their parents $(6.44 \pm 2.01$ in ADHD group versus $6.71 \pm 2.28$ in control group, $p=0.442$ ).

A final word to the biggest challenges/difficulties reported by caregivers relating to themselves or to their children, which were, by far, the difficulty in monitoring home school and to deal with isolation. 
Table 3. Results concerning to details of quarantine

\begin{tabular}{|c|c|c|c|c|}
\hline & All $(n=152)$ & ADHD $(n=90)$ & Control $(n=62)$ & $p$ value \\
\hline Days in quarentine (dys) - mean $\pm S D$ & $33.2 \pm 5.8$ & $33.13 \pm 4.33$ & $33.29 \pm 7.38$ & 0.157 \\
\hline \multicolumn{5}{|l|}{ Went out during quarantine? - $n(\%)$} \\
\hline Yes & $87(57.2)$ & $55(61.1)$ & $32(51.6)$ & \\
\hline No & $65(42.8)$ & 35 (38.9) & $30(48.4)$ & \\
\hline How many times? (dys) - mean $\pm S D$ & $4.60 \pm 0.97$ & $4.49 \pm 1.04$ & $4.77 \pm 0.85$ & 0.286 \\
\hline Home schooling - $n(\%)$ & & & & 0.002 \\
\hline Yes & $109(71.7)$ & $56(62.2)$ & $53(85.5)$ & \\
\hline No & $43(28.3)$ & $34(37.8)$ & $9(14.5)$ & \\
\hline Extracurricular activity - $\mathrm{n}(\%)$ & & & & 0.421 \\
\hline Yes & $115(75.7)$ & $66(73.3)$ & $49(79.0)$ & \\
\hline No & $37(24.3)$ & $24(26.7)$ & $13(21.0)$ & \\
\hline \multicolumn{5}{|l|}{ Mantain extracurricular acitivity - $n(\%)$} \\
\hline Yes & $26(17.1)$ & $11(19.6)$ & $15(24.2)$ & \\
\hline No & $83(54.6)$ & $45(80.4)$ & $38(61.3)$ & \\
\hline Mantain routines - $n(\%)$ & & & & 0.675 \\
\hline Yes & $68(44.7)$ & $39(43.3)$ & $29(46.8)$ & \\
\hline No & $84(55.3)$ & $51(56.7)$ & $33(53.2)$ & \\
\hline Tasks at home - $\mathbf{n}(\%)$ & & & & 0.680 \\
\hline Yes & $113(74.3)$ & $68(75.6)$ & $45(72.6)$ & \\
\hline No & $39(25.7)$ & $22(24.4)$ & $17(27.4)$ & \\
\hline Behaviour change - $n(\%)$ & & & & 0.035 \\
\hline Yes & $68(44.7)$ & $47(52.2)$ & $21(33.9)$ & \\
\hline No & $85(55.9)$ & $44(48.9)$ & $41(66.1)$ & \\
\hline Type of behaviour change & & & & \\
\hline Better & $18(26.5)$ & $11(23.4)$ & $7(33.3)$ & \\
\hline Worse & $50(73.5)$ & $36(76.6)$ & $14(66.7)$ & \\
\hline Learning impact - $n(\%)$ & & & & 0.599 \\
\hline Positive & $24(15.8)$ & $12(13.3)$ & $12(19.4)$ & \\
\hline Negative & $83(54.6)$ & $51(56.7)$ & $32(51.6)$ & \\
\hline None & $45(29.6)$ & $27(30.0)$ & $18(29.0)$ & \\
\hline Impact in development - $\mathrm{n}(\%)$ & & & & 0.05 \\
\hline Positive & 47 (30.9) & $21(23.3)$ & $26(41.9)$ & \\
\hline Negative & $46(30.3)$ & $30(33.3)$ & $16(25.8)$ & \\
\hline None & $59(38.8)$ & $39(43.3)$ & $20(32.3)$ & \\
\hline Impact in emotions - $\mathrm{n}(\%)$ & & & & 0.387 \\
\hline Positive & $49(32.2)$ & $26(28.9)$ & $23(37.1)$ & \\
\hline Negative & $48(31.6)$ & $32(35.6)$ & $16(25.8)$ & \\
\hline None & $55(36.2)$ & $32(35.6)$ & $23(37.1)$ & \\
\hline Impact in family relations - $\mathrm{n}(\%)$ & & & & 0.021 \\
\hline Positive & $66(43.4)$ & $31(34.4)$ & $35(56.5)$ & \\
\hline Negative & $18(11.8)$ & $11(12.2)$ & $7(11.3)$ & \\
\hline None & $68(44.7)$ & $48(53.3)$ & $20(32.3)$ & \\
\hline Child anxiety score (0 to 10$)$ - mean $\pm S D$ & $4.65 \pm 2.77$ & $5.34 \pm 2.68$ & $3.65 \pm 2.61$ & $\mathrm{p}<0.001$ \\
\hline Parents anxiety score (0 to 10 ) - mean $\pm S D$ & $6.55 \pm 2.47$ & $7.27 \pm 2.35$ & $5.52 \pm 2.28$ & $\mathrm{p}<0.001$ \\
\hline Child adaptation score (0 to 10$)$ - mean $\pm S D$ & $7.14 \pm 2.20$ & $7.03 \pm 1.94$ & $7.29 \pm 2.55$ & 0.504 \\
\hline Parents adaptation score (0 to 10 )- - & $6.55 \pm 2.12$ & $6.44 \pm 2.01$ & $6.71 \pm 2.28$ & 0.442 \\
\hline
\end{tabular}

\section{DISCUSSION}

The most common impacts of an epidemic in children are anxiety, panic behavior and sleep disturbances (Jiao et al., 2020; Khan et al., 2020). Currently, during the COVID-19 pandemic, it is given high warning to the physical health. Nevertheless, psychological health can't be ignored (Brooks et al., 2020; Khan et al., 2020; Lima et al., 2020).

ADHD is associated with social difficulties and emotion dysregulation (Classi et al., 2012; Shaw et al., 2014; Teixeira et al., 2019; Williams et al., 2008) that can lead to conflicts with family. In our study, parents of children with ADHD reported significantly more changes in behavior and mostly 
no impact in family relations when compared to those in control group, while parents of the control group reported mostly a positive impact in family relations during quarantine. The most frequently described changes in behavior was anxiety and agitation. A study from China (Zhang et al., 2020) focusing children with ADHD during the COVID-19 outbreak also showed that ADHD diagnosed children's behavior significantly worsen comparing to their normal state and that parent's mood also impact children's symptoms. In our sample, the impact of the quarantine in emotions seems to be equivalent between both groups, and this could be related to the fact that, during quarantine, ADHD children's don't have to deal with school demands, rules, and high social pressure, often seen as a major challenge in this group (Chen et al., 2020; Classi et al., 2012; Hartman et al., 2019; Oster et al., 2020; Rushton et al., 2020). Furthermore, the increase in the consumption of videogames and screens was frequently reported by the parents during this period.

Negative impact in learning were reported by the parents of both groups with no statistically differences, what supports the theory that school closedown is a serious challenge to everyone, even in healthy and without neurodevelopmental impairment children (Shuja et al., 2020; Wagner, 2020). In addition, most parents pointed out the difficulty in monitoring home school as the biggest challenge they face during quarantine.

Although there are few published studies on this subject, some researchers have stated that children who are quarantined may be experiencing high levels of stress and are vulnerable to develop serious mental abnormalities (Jiao et al., 2020; Liu et al., 2020). A study conducted by Moccia et al., 2020, on the Italian general population during COVID-19 pandemic, showed that $38 \%$ of the individuals reported mild or moderate-to-severe psychological distress. Cao et al., 2020 also exhibited that 24.9\% of student's sample from a Chinese college experienced anxiety due to COVID-19 outbreak. Indeed, in our study, children with ADHD and their parents had higher levels of stress/anxiety than healthy ones during the outbreak, suggesting that both children with ADHD and their caregivers may be a risk group to pay attention to, in what concerns to psychological health during the COVID-19 pandemic.

Interestingly, caregivers of both groups reported higher stress levels in themselves compared to their own children. This information should alert physicians to the importance of red flags' recognition, not only in children but also in their parents, as well as strategies' provision to the whole family to deal with the COVID-19 outbreak. In this subject, we highlight that The International Paediatric Association provided guidance for physicians to manage children's health during COVID19 (Klein et al., 2020). Likewise, WHO, UNICEF and others have developed guidance for support families to stress management including ways to explain the pandemic to their children (Healthy Children, 2020; Save the Children, 2020; US Centers for Disease Control and Prevention, 2020; UNICEF, 2020; WHO, 2020).

Nonetheless, our study has also some limitations. The data collected online through email sent questionnaire, which was mostly answered by parents of healthy children, may have a bias of a higher graduated population and possibly with greater capacity for coping strategies. Additionally, all data were reported by parents rather than reported by children directly.

In conclusion, the effects of COVID-19 pandemic on mental health have not been studied systematically, yet our results alert to the importance of focusing on special vulnerable groups and to the post-pandemic investigation of mental disorders among families.

\section{REFERENCES}

American Academy of Pediatrics. (2000). Clinical practice guideline: diagnosis and evaluation of the child with attention-deficit/hyperactivity disorder. Pediatrics, 105, 1158-1170. 
American Psychiatric Association. (2003). Diagnostic and statistical manual of mental disorders (DSM-5).

Brooks, S. K., Webster, R. K., Smith, L., Woodland, L., Wessely, S., Greenberg, N., \& Rubin, G.J. (2020). The psychological impact of quarantine and how to reduce it: rapid review of the evidence. The Lancet, 395, 10227. https://doi.org/10.1016/S0140-6736(20)30460-8.

Cao, W., Fang, Z., Hou, G., Han, M., Xu, X., Dong, J., \& Zheng, J. (2020). The psychological impact of the COVID-19 epidemic on college students in China. Psychiatry Research, 287, 112934. https://doi.org/10.1016/j.psychres.2020.112934.

Chen, Y-L., Ho, H-Y., Hsiao, R. C., Lu, WH., \& Yen, C.F. (2020). Correlations between Quality of Life, School Bullying, and Suicide in Adolescents with Attention-Deficit Hyperactivity Disorder. International Journal of Environmental Research and Public Health, 17, 3262. https://doi.org/10.3390/ijerph17093262.

Cheung, K., \& Theule, J. (2016). Parental psychopathology in families of children with ADHD: A meta-analysis. Journal of Child and Family Studies, 25(12), 3451-3461. https://doi.org/10.1007/s10826-016-0499-1.

Classi, P., Milton, D., Ward, S., Sarsour, K., \& Johnston, J. (2012). Social and emotional difficulties in children with ADHD and the impact on school attendance and healthcare utilization. Child and Adolescent Psychiatry and Mental Health, 6, 33. https://doi.org/10.1186/1753-2000-6-33.

Craig, F., Savino, R., Fanizza, I., Lucarelli, E., Russo, L., \& Trabacca, A. (2020). A systematic review of coping strategies in parents of children with attention deficit hyperactivity disorder (ADHD). Research in Developmental Disabilities, 98, 103571. https://doi.org/10.1016/j.ridd.2020.103571.

Hartman, C. A., Rommelse, N., van der Klugt, C. L., Wanders, R. B. K., \& Timmeman, M. E. (2019). Stress Exposure and the Course of ADHD from Childhood to Young Adulthood: Comorbid Severe Emotion Dysregulation or Mood and Anxiety Problems. Journal of Clinical Medicine, 8, 1824. https://doi.org/10.3390/jcm8111824.

Healthy Children. Parenting in a Pandemic: Tips to Help Keep the Calm at Home. [Accessed 24 September 2020]. Available at https:/www.healthychildren.org/English/healthissues/conditions/COVID-19/Pages/Parenting-in-a-Pandemic.aspx

Jiao, W. Y., Wang, L. N., Liu, J., Fang, S. F., Jiao, F. Y., Pettoello-Mantovani, M., \& Somekh, E. (2020). Behavioral and Emotional Disorders in Children during the COVID-19 Epidemic. The Journal of Pediatrics, 221 , 264-266. https://doi.org/10.1016/j.jpeds.2020.03.013.

Khan, S., Siddique, R., Li1, H., Ali, A., Shereen, M. A., Bashir, N., \& Xue, M. (2020). Impact of coronavirus outbreak on psychological health. Journal of Global Health, 10(1), 010331. https://doi.org/10.7189/jogh.10.010331.

Klein, J. D., Koletzko, B., El-Shabrawi, M. H., Hadjipanayis, A., Thacker, N., \& Bhutta. Z. (2020). Promoting and supporting children's health and healthcare during COVID-19 - International Paediatric Association Position Statement. Archives of Disease in Childhood, 105(7), 620-624. https://doi.org/10.1016/j.psychres.2020.112934.

Lima, C., Carvalho, P., Lima, I., Nunes, J., Saraiva, J., \& Souza, R. (2020). The Emotional Impact Of Coronavirus 2019-Ncov (New Coronavirus Disease). Psychiatry Research, 287, 112915. https://doi.org/10.1016/j.psychres.2020.112915.

Liu, J. J., Bao, Y., Huang, X., Shi, J., \& Lu, L. (2020). Mental health considerations for children quarantined because of COVID-19. Lancet Child \& Adolescent Health, 4, 347-349. https://doi.org/10.1016/S2352-4642(20)30096-1.

Martin, C. A., Papadopoulos, N., Chellew, T., Rinehart, N. J., \& Sciberras, E. (2019). Associations between parenting stress, parent mental health and child sleep problems for children with ADHD and ASD: Systematic review. Research in Developmental Disabilities, 93, 103463. https://doi.org/10.1016/j.ridd.2019.103463. 
Moccia, L., Janiri, D., Pepe, M., Dattoli, L., Molinaro, M., Martin V., Chieffo, D., Janiri, L., Fiorillo, A., Sani, G., \& Di Nicola, M. (2020). Affective temperament, attachment style, and the psychological impact of the COVID-19 outbreak: an early report on the Italian general population. Brain, Behavior, and Immunity, 87, 75-79. https://doi.org/10.1016/j.bbi.2020.04.048.

Oster, C., Ramklint, M., Meyer, J., \& Isaksson, J. (2020). How do adolescents with ADHD perceive and experience stress? An interview study. Nordic Journal of Psychiatry, 74(2), 123-130. https://doi.org/10.1080/08039488.2019.1677771.

Reimherr, F. W., Marchant, B. K., Gift, T. E., \& Steans, T. A. (2017). ADHD and Anxiety: Clinical Significance and Treatment Implications. Current Psychiatry Reports, 19(12), 109. https://doi.org/10.1007/s11920-017-0859-6.

República Portuguesa (2020). Comunicação enviada às escolas sobre a suspensão das atividades com alunos nas escolas de 16 de março a 13 de abril. [Accessed 24 September 2020]. Available at: https://www.portugal.gov.pt/pt/gc22/comunicacao/documento? $\mathrm{i}=$ comunicacao-enviada-asescolas-sobre-suspensao-das-atividades-com-alunos-nas-escolas-de-16-de-marco-a-13-de-abril.

Rushton, S., Giallo, R., \& Efron, D. (2020). ADHD and emotional engagement with school in the primary years: Investigating the role of student-teacher relationships. British Journal of Educational Psychology, 90(S1), 193-209. https://doi.org/10.1111/bjep.12316.

Save the Children. Support for parenting during coronavirus. [Accessed 24 September 2020]. Available at: https://www.savethechildren.net/support-parenting-during-coronavirus.

Schroeder, V. M., \& Kelley, M. L. (2009). Associations between family environment, parenting practices, and executive functioning of children with and without ADHD. Journal of Child and Family Studies, 18(2), 227-235. https://doi.org/10.1007/s10826-008-9223-0.

Shaw, P., Stringaris, A., Nigg, J., \& Leibenluft, E. (2014). Emotion dysregulation in attention deficit hyperactivity disorder. American Journal of Psychiatry, 171(3), 276-93. https://doi.org/10.1176/appi.ajp.2013.13070966.

Shuja, K.H., Aqeel, M., Jaffar, A., \& Ahmed, A. (2020). COVID-19 pandemic and impending global mental health implications. Psychiatria Danubina, 32(1), 32-35. https://doi.org/10.24869/psyd.2020.32.

Silva, R. S., Corujeira, S., Reis-Melo, A., Almeida, P., Viana, V., \& Guardiano, M. (2015). Evaluation of parenting stress in mothers of children with attention deficit hyperactivity disorder. Acta Pediátrica Portuguesa, 46, 299-304.

Teixeira, S., Barbosa, J.P., Lourenço, L., Gonçalves, D., \& Guardiano, M. (2019). Avaliação da alexitimia em crianças portuguesas com perturbação de hiperatividade/défice de atenção. Gazeta Médica, 6(2). https://doi.org/10.29315/gm.v6i2.240.

Wagner, K. D. (2020). Addressing the experience of children and adolescents during the COVID-19 $\begin{array}{lllll}\text { pandemic. The Journal of Clinical Psychiatry, } & \text { 81(3), } & 13394 .\end{array}$ https://doi.org/10.4088/JCP.20ed13394.

Williams, L. M., Hermens, D. F., Palmer, D., Kohn, M., Clarke, S., Keage, H., Clark, R. C., \& Gordon, E. (2008). Misinterpreting emotional expressions in attention-deficit/hyperactivity disorder: evidence for a neural marker and stimulant effects. Biological Psychiatry, 6(10), 917-26. https://doi.org/10.1016/j.biopsych.2007.11.022.

World Health Organization (2020). Coronavirus disease (COVID-19) advice for the public: healthy parenting. [Accessed 24 September 2020]. Available at: https://www. who. int/ emergencies/ diseases/ novelcoronavirus-2019/ advice- for- public/ healthy- parenting.

World Health Organization (2020). Director-General's opening remarks at the media briefing on COVID19 - March 2020. [Accessed 24 September 2020]. Available: https://www.who.int/dg/speeches/detail/who-director-general-s-opening-remarks-at-the-mediabriefing-on-covid-19---11-may-2020. 
World Health Organization (2020). Doing What Matters in Times of Stress: An Illustrated Guide. [Accessed 24 September 2020]. Available at: https://www.who.int/publications/i/item/9789240003927

UNICEF (2020). Coronavirus disease: tips and guidance for families. [Accessed 24 September 2020] Available at: https://www.unicef.org/parenting/coronavirus-covid-19-guide-parents

US Centers for Disease Control and Prevention (CDC). Coronavirus disease. Coping and Stress. [Accessed 24 September 2020]. Available at: https://www.cdc.gov/coronavirus/2019-ncov/dailylife-coping/managing-stress-anxiety.htm

Zhang, J., Shuai, L., Yu, H., Wang, Z., Qiu, M., Lu, L., Cao, X., Xia, W., Wang, Y., \& Chen, R. (2020). Acute stress, behavioural symptoms and mood states among school-age children with Attention-Deficit/Hyperactive Disorder during the COVID-19 outbreak. Asian Journal Psychiatry, 51, 102077. https://doi.org/10.1016/j.ajp.2020.102077. 